Wyrok Sądu Metropolitalnego w Katowicach (w trzeciej instancji) c. Sobański z 2 września 1997 r. w sprawie o nieważność małżeństwa z tytułu braku wystarczającego rozeznania i niezdolności do podjęcia istotnych obowiązków małżeńskich : zgodność wyroków

Ius Matrimoniale 3 (9), 207-216

1998

Artykuł został zdigitalizowany i opracowany do udostępnienia w internecie przez Muzeum Historii Polski w ramach prac podejmowanych na rzecz zapewnienia otwartego, powszechnego i trwałego dostępu do polskiego dorobku naukowego i kulturalnego. Artykuł jest umieszczony w kolekcji cyfrowej bazhum.muzhp.pl, gromadzącej zawartość polskich czasopism humanistycznych i społecznych.

Tekst jest udostępniony do wykorzystania w ramach dozwolonego użytku. 
Ius Matrimoniale

3 (1998)

\section{Wyrok Sądu Metropolitalnego w Katowicach \\ c. Sobański z 2 września 1997 r. w sprawie o nieważność malżeństwa $z$ tytułu braku wystarczającego rozeznania i niezdolności do podjęcia istotnych obowiązków malżeńskich (zgodność wyroków).}

\section{PRZEBIEG SPRAWY:}

BM (...) oraz MK (...) zawarli dnia 8.7.1972 małżeństwo w kościele parafialnym św. B. w P. (taka data widnieje na świadectwie ślubu, wedle stron małżeństwo zawarto dwa tygodnie później). Ważność tego małżeństwa została 1.6.1989 zaskarźona przez BM w Sądzie Diecezji (...) z tytułu niezdolności pozwanej do przyjęcia istotnych obowiązków małżeńskich oraz z tytułu symulacji powoda i pozwanej. Wyrokiem z 29.I.1991 Sąd ten orzekł, iż nie udowodniono nieważności małżeństwa $\mathrm{z}$ żadnego tytułu. Pismem z 14.3.1992 powód odwołał się do wyroku do Trybunału II instancji. W Trybunale apelacyjnym ustalono jeszcze jeden tytuł nieważności, mianowicie niezdolność powoda do podjęcia istotnych obowiązków małżeńskich. Dnia 31.10.1994 Sąd II instancji orzekł, iż nie udowodniono nieważności małżeństwa $z$ tytułu symulacji czy to powoda czy to pozwanej, udowodniono natomiast nieważność małżeństwa $\mathrm{z}$ tytułu niezdolności powoda do podjęcia istotnych obowiązków małżeńskich oraz z tytułu niezdolności pozwanej do podjęcia istotnych obowiązków małżeńskich. $Z$ tych dwóch więc tytułów $S a ̨ d$ ten uchylił wyrok I instancji. Strony poinformowano o wyroku 10.I.1996, jego odpis przesłano powodowi 17.2.1996, pozwanej 22.3.1996. Ze względu na k. 1682 \& 1 oficjał Sądu (...) zwrócił się w imieniu powoda do Najwyższego Trybunału Sygnatury Apostolskiej o wyznaczenie któregoś z sądów kościelnych w Polsce do rozpatrzenia sprawy w trzeciej instancji. Przychylając się do tej prośby Trybunał Sygnatury Apostolskiej dekretem z 21.2.1997 (Prot. N.27569/97 C.P.) wyznaczył Sąd Metropolitalny w Katowicach do rozpatrzenia i rozstrzygnięcia sprawy w trzeciej instancji. Dnia 17.3.1997 ustalono 
personalny skład Trybunału. Powód nie przedstawił dalszych wniosków dowodowych, pozwana nie zareagowała na pisma Sądu. Sąd ma przeto odpowiedzieć na pytanie, czy należy zatwierdzić wyrok Trybunału II Instancji w części orzekającej nieważność małżeństwa, co jest równoznaczne z pytaniem, czy udowodniono nieważność małżeństwa $\mathrm{z}$ tytułu niezdolności pozwanej do podjęcia istotnych obowiązków małżeńskich oraz/lub z tytułu niezdolności powoda do podjęcia istotnych obowiązków malżeńskich. Na te pytania Sąd Metropolitalny w Katowicach udzielił dnia 2 września 1997 następującej odpowiedzi.

\section{STAN PRAWNY:}

1. Wedle kan. 10995 n. 3 „Niezdolni do zawarcia małżeństwa sq̨ ci, którzy (...) z przyczyn natury psychicznej nie są zdolni podjąć istotnych obowiązków małżeńskich". W świetle orzecznictwa kościelnego wśród przyczyn takiej niezdolności rysuje się bezspornie uzależnienie alkoholowe (wskazane w motywacji prawnej wyroku II instancji) oraz brak odpowiedniej, „,kanonicznej”, dojrzałości do małżeństwa. Alkoholik wykazuje cechy niedojrzałości osobowościowej w postaci niewrażliwości na wartości wyższe, niskiej odporności na frustracje, stosowania nieadekwatnych mechanizmów obronnych, koncentruje swe starania i zabiegi wokół alkoholu, staje się obojętny i nieczuły na sytuacje bliźnich, stąd jego niezdolność do ,wyjścia poza siebie" niezbędnego do nawiązania wspólnoty małżeńskiej. To „wyjście poza siebie" wymaga też wystarczającej dojrzałości. Nie chodzi o pełną dojrzałość, lecz o taką, która przymierza się z punktu widzenia istoty małżeństwa, a której istnienie domniewa się $\mathrm{z}$ dojściem do wieku uznanego za wystarczający do zawarcia małzeństwa. Dojrzałość jest czymś dynamicznym, osiąganym w kolejnych fazach życia, dojrzałość kanoniczna w odniesieniu do małżeństwa jest przeto „minimalnym punktem wyjścia dla ważności małżeństwa" (Jan Paweł II, przemówienie z 5.2.1987). O braku takiej dojrzałości moźna tylko wtedy mówić, gdy nupturient w chwili zawierania małżeństwa nie osiągnął ,pewnej przeciętnej”, czyli wtedy, gdy osobowość wykazuje cechy nieprawid lowe.

2. W rozpatrywanej sprawie trzeba zwrócić szczególną uwagę na kanoniczne zasady dowodzenia i kryteria osiągnięcia moralnej pewności. Samo „załamanie się jakiegoś związku małżeńskiego nigdy nie może stanowić 
dowodu służącego wykazaniu owej niezdolności kontrahentów (Jan Paweł II, przem. j.w.). Sąd musi retrospektywnie stwierdzić, czy załamanie się małżeństwa wynikło $\mathrm{z}$ niezdolności kontrahentów do podjęcia istotnych obowiązków malżeńskich - $\mathrm{i}$ to niezdolności spowodowanej przyczynami natury psychicznej (w rozpatrywanej sprawie: alkoholizmem pozwanej i niedojrzałością powoda). W sprawach $\mathrm{z}$ tego tytułu Sąd obligatoryjnie korzysta $z$ pomocy jednego lub kilku biegłych (k. 1680). Wnioski biegłych sędzia winien uważnie rozważyć, a w uzasadnieniu decyzji podać argumenty, jakie skłoniły go do przyjęcia lub odrzucenia wniosków biegłych (k. 1579 §2). Konieczność przedstawienia tych argumentów, wynikająca z samej natury dowodu $\mathrm{z}$ biegłych, służących sądowi swoją wiedzą fachową, jest tym większa gdy orzeczenie sądu odbiega od wniosków biegkego. Ze względu na to, że domniemanie prawne przemawia za ważnością malżeństwa (k.1060) co znaczy, że w razie nieosiągnięcia pewności o nieważności trzeba orzec, iż nie udowodniono nieważności. Szczególnie przejrzystego uzasadnienia wymaga odejście od ich opinii w wyroku orzekającym nieważność małżeństwa. Orzeczenie takie wymaga bowiem osiągnięcia moralnej pewności o nieważności (k. 1608 §1), tj. takiej, której nie można przeciwstawić uzasadnionych wątpliwości. Trzeba więc wykazać, dlaczego - oparte na fachowej wiedzy, której sędzia nie posiada - wnioski biegłych nie dostrzegających podstaw niezdolności do podjęcia istotnych obowiązków małżeńskich nie przeszkadzają osiągnięciu pewności o istnieniu owej niezdolności. Zaniechanie rozprawienia się z wnioskami biegłych oznaczałoby ignorowanie dowodów.

3. Rozpatrywana sprawa wymaga wyjaśnienia wzajemnej relacji podstaw nieważności, o których w k. 1095. W wyroku II instancji stwierdza się bowiem, iż pozwany zawierając małżeństwo miał ograniczoną swobodę decyzji i znajdował się w sytuacji ograniczającej jego rozeznanie oraz jego możliwość racjonalnego rozwiązania sytuacji. W grę wchodziłaby przeto norma k. 1095 n. 2, podczas gdy Trybunał orzekł z k. 1095 n. 3. Rodzi się przeto pytanie, czy normy k. $1095 \mathrm{n} .2$ oraz k.1095 n.3 stanowią autonomiczne tytuły nieważności. Na pytanie to trzeba odpowiedzieć twierdząco. W k. 1095 n.2 (podobnie jak w k.1095 n.1) chodzi o psychiczne elementy samego konsensu małżeńskiego, zaś w k. 1095 n.3 o przedmiot tego konsensu. Czyli: w przypadku k.1095 n.1 i 2 chodzi o psychiczną zdolność do świadomego wyrażenia konsensu, zaś k. 1095 n.3 o zdolność do przyjęcia i przekazania tego wszystkiego, co w sposób istotny składa się na małżeństwo. W tym ostatnim przypadku rozeznanie i możność kierowania swoim postępowa- 
niem mogą nie podlegać brakom czy ograniczeniom, natomiast przekaz praw jest czczy. Może zaistnieć też sytuacja odwrotna: osoba zdolna do wypełnienia obowiązkéw małżeńskich może w chwili zawierania malżeństwa cierpieć na poważny brak rozeznania, o którym w k. 1095 n.2. W dyspozycji tej nie chodzi o brak używani: rozumu (jak w k.1095 n.1) wynikły z choroby psychicznej lub niedorozwoju ui: ysłowego, lecz o rozeznanie oceniające, na które składa się nie tylko poznanie, lecz ocena czyli zdolność wydania sądu o zawieranym małżenstwie, oraz wolno.ć wewnętrzna umożliwiająca świadomy wybór. Brak rozeznania oceniającego może iść w parze ze zdolnością do wypełniania istotnych obowiązków małżenskich. Ma to miejsce wtedy, gdy zawierający małżeństwo znalazł sie w sytuacji uniemożliwiającej rozważenie motywów zawarcia małżeństwa, albo gdy okoliczności zewnętrzne upośledzały jego rozeznanie sytuacji - wtedy gdy zawierający małżeństwo „pogubił się", przestał być panem sytuacji.

Trzeba wreszcie przypomnieć, że aczkolwiek każda z trzech norm k. 1095 stanowi autonomiczny tytuł nieważności małżeństwa, to granica między nimi nie zawsze rysuje się wyraziście, gdyż człowiek to pewna jedność i całość psychiczna. Moga bowiem zachodzić takie przyczyny natury psychicznej, które zarówno pozbawiają wystarczającego rozeznania, jak też czynią osobę niezdolną do podjęcia istotnych obowiązków małżeńskich (k.1095 n.1 wchłania k. 1095 n.3), Moga jednak też zachodzić takie przyczyny psychicznej natury, które powodują niezdolność do zawarcia małżeństwa tylko z racji podanych $w n .2$ lub n. 3 k.1095. Trzeba przeto $w$ każdym przypadku ustalić, z czego wynika powodowana racjami psychicznymi niezdolność do zawarcia małżeństwa.

4. Skoro tytuły nieważności małżeństwa odwołujące się do k. 1095 n.2 lub n.3 są autonomiczne, trzeba - wobec orzeczenia Trybunału II instancji - postawić pytanie, czy wyrok orzekający nieważność małżeństwa z k. 1095 n. 2 można by uznać za zgodny $z$ wyrokiem orzekającym $z$ k. 1095 n.3. Wedle k.1641 n.1 wyroki są zgodne, jeśli zapadły ,między tymi samymi stronami, co do tego samego żądania i $z$ tego samego tytułu roszczenia". Nie można mówić o zgodności wyroków, jeśli różnią się co do jednego $\mathrm{z}$ powyższych trzech wyznaczników zgodności (sent.c. Palestro z 31.1.1990 - RRT Dec. $82,1994,58)$. W świetle tego, co powiedziano wyżej, należy stwierdzić, że k. 1095 n.2 i k. 1095 n.3 zawierają różne tytuły roszczenia. Trzeba jednak zauważyć, że tytuł sprawy zostaje sformułowany przez sędziego (k.1677 §2). On ustala przesłankę większą sylogizmu prowadzącego do wyroku, przesłan- 
ka ta tworzy pewną całość z przesłanką mniejszą, wykazaną w stanie faktycznym, do sędziego należy właściwy dobór przesłanki większej, tzn. przepisów prawa.

Powód wnosi o orzeczenie nieważności małżeństwa i podaje fakty, które -jego zdaniem - tę niewaźność uzasadniają, natomiast sąd musi zgodnie z k. 1608 uwzględnić wszystko, co konieczne dla wydania słusznego, zgodnego z obiektywną prawdą wyroku. Należy do tego także właściwe prawne sformułowanie przedmiotu sporu, w myśl zasady ,iura novit curia" (sent. c. Serrano z 24.10.1986 - MonEccl 114,1989,287). W procesie o niewaźność małżeństwa właśnie ta nieważność jest przedmiotem sporu. Tytuły nieważności formułuje się do ukierunkowania i skoordynowania procesu, nieważność ma zawsze prawne i faktyczne podstawy, opiera się na tzw. faktach prawnych. Ustalenie tych podstaw $w$ zawieraniu sporu ma zapobiec rozmyciu się postępowania, nie wyklucza jednak, że w trakcie instrukcji moga wyłonić się inne aspekty sprawy. Wyświetlanie stanu faktycznego naprowadza na inne, nie uwzglednione na początku normy prawne znajdujące zastosowanie do sprawy. Gromadzenie materiału dowodowego i kompletowanie znajdujących zastosowanie przepisów pozostaje we wzajemnym sprzężeniu, przypadek ustala się pod kątem wchodzących w grę przepisów, przepisy wyszukuje się i uwzględnia ze względu na przypadek. Tak też $w$ trakcie procesu może się ujawnić nowy tytuł nieważności, zwłaszcza w sprawach $\mathrm{z}$ wady konsensu spowodowanej przyczynami psychicznymi. Oddalenie powództwa dlatego, że w trakcie procesu okazało się, iż należało przyporządkować stanowi faktycznemu inny tytuł sprawy, byłoby naruszeniem sprawiedliwości. Nie można wprawdzie w tym kontekście nie zwrócić uwagi na k.1514 zabraniający zmiany zakresu sporu bez poważnej racji i wysłuchania stron. Ale właśnie te racje zachodzą, stanowi je prawo stron do sprawiedliwego, odpowiadającego wprawdzie wyroku. Obowiązek wydania takiego wyroku każe sądowi powołać się na te normy prawa, które dla danego przypadku stanowią iż małżeństwo jest nieważne. Jeśli więc fakty prawne nagromadzone w sprawie prowadzonej z k. 1095 n.3 uzasadniaja orzekanie $\mathrm{z}$ k. $1095 \mathrm{n} .2$, sąd winien orzekać $\mathrm{z}$ tegoż właśnie tytułu. Inny wniosek byłby nieracjonalny, znaczyłby bowiem, że dwa sądy opierające się na tych samych dowodach są przekonane o nieważności małżeństwa, ale ponieważ różnią się co do wchodzących w grę norm prawnych, skazują strony na nowe wniesienie sprawy, a przynajmniej na rozpatrywanie jej w kolejnej instancji. Byłoby to wbrew sprawiedliwości i wbrew zamysłowi 
prawodawcy, który stanowi normy (małżeńskie i procesowe) dla - postrzeganych $w$ ich stężeniu - ochrony małżeństwa i dobra dusz. Normy procesowe, w tym także ustalenie tytułu sprawy, ma słuźyć dojściu do prawdy, a nie orzekaniu obok niej. („Canoni relativi non possono essere considerati come delle ricette o come delle etichette da applicarsi formalisticamente senza discrezione. Il processo è viva, aderente alle realtà, e il suo intento è di scoprire, attraverso una equilibrata dialettica, laverità della cosa" - P. Felici, Formalitates iuridicae et aestimatio probatiobnum in processu canonico, Communicationes 9, 1977, 180).

Odnosząc powyższe do rozpatrywanej sprawy trzeba przypomnieć, że zgodność wyroków to nie ich identyczność (sent. c. Serrano,j.w.), Orzecznictwo rotalne uznaje - co od r.1971 jest zasada (L'Attività della Santa Sede nel 1971. Pubblicazione non ufficiale, Città del Vaticano 1971, $712 \mathrm{~ns})-\dot{z e}$ wyroki sq równoważne zgodne (,,aequivalenter confirmativa habenda sit" - sent. c. Mattioli z 4.12.1957, Dec. 49,1957,807), jeśli orzeczenie, acz $\mathrm{z}$ różnych tytułów, opiera się na tych samych dowodach i argumentach (sent. c. Palestro, j.w., z powołaniem wielu wyroków Trybunału Roty Rzymskiej): nie chodzi o nazwę, lecz o fakty prawne, którymi motywuje się wyrok. Nie można natomiast uznać za zgodne wyroki odwołujące się do różnych faktów i dowodów (STSA, dec. z 10.2.1971 - Periodica 60, 1971, 315-319).

Wyroki są równoważne zgodne (,aequivalenter conformis" - sent. c. Brennan z 21.11.1958, Dec. 50, 1958, 610, i inne), jeśli wprawdzie różnią się co do tytułu (przesłanka większa), lecz są zgodne co do faktów prawnych (przesłanka mniejsza) i orzeczenia (konkluzja), oczywiście pod warunkiem poprawności rozumowania, co znaczy, że zebrany materiał dowodowy daje zgodnie $\mathrm{z}$ regułami dowodzenia moralną pewność ( $w$ tym przypadku) o nieważności małżeństwa.

\section{STAN FAKTYCZNY:}

1. Zarówno Trybunał I instancji, jak też Trybunał II instancji, zasiegnął opinii biegłych. Biegła I instancji wypowiedziała się jedynie o zdolności pozwanej do podjęcia istotnych obowiązków małżeńskich (zdolności powoda nie kwestionowano w I instancji). Biegla w sumiennie opracowanej opinii, opartej na aktach sprawy i badaniu pozwanej, wyraża pogląd, że pozwana „była zd olna do odpowiedzialnego podjęcia i wypełnienia istotnych obowią- 
zków małżeńskich" (I. k.64). Biegła nie znalazla bowiem podstaw do stwierdzenia u pozwanej alkoholizmu lub uzależnienia od alkoholu, a to miało być źródłem niezdolności do podjęcia istotnych obowiązków małżeńskich. Do identycznego wniosku doszedł też biegły powolany w II instancji (k.48).

Zgodnie $\mathrm{z}$ wniesionym $\mathrm{w}$ II instancji dodatkowym tytukem sprawy Trybunal zwrócił się do bieglego o opinię dotyczącą zdolności powoda do podjęcia istotnych obowiązków małżeńskich. Wnioski biegłego brzmią następująco: „Na podstawie dość skąpego materiału dowodowego można stwierdzić u powoda cechy niedojrzałości emocjonalnej uwarunkowanej rozwojowo. Powód $\mathrm{z}$ racji młodego wieku był materialnie uzależniony od rodziców. Wiadomo, że znajdowal się wówczas w trudnej sytuacji psychologicznej (ciąża pozwanej i presja rodziny), której nie potrafił racjonalnie rozwiązać. W/w okoliczności ograniczały zdolność powoda do swobodnego podjęcia decyzji zawarcia małżeństwa. Brak jest natomiast dowodów na to, aby powód był psychicznie niezdolny do wypełnienia istotnych obowiązków małżeńskich" (II, 61). Tak więc dowód $\mathrm{z}$ biegłych prowadzi do wniosku, iż obydwie strony były zdolne do podjeccia istotnych obowiązków małżeńskich.

Mimo takiej opinii biegłych Trybunał II instancji orzekł, iż udowodniono nieważność małżenstwa $\mathrm{i}$ to $\mathrm{z}$ tytułu niezdolności zarówno pozwanej, jak i powoda do wypelnienia istomych obowiązków malżeńskich. W wyroku przytacza się wnioski biegłych, ale nie polemizuje $z$ nimi, trudno więc dostrzec racje, które skłoniły Trybunał do odrzucenia wniosków biegłych. Niezależnie od opinii biegłych Trybunał przedstawia własne ustalenia odnośnie do pozwanej i powoda.

2. Odnośnie do pozwanej Trybunał II instancji stwierdza, że w chwili zawarcia małżeństwa miała dopiero 19 lat, nie była osobą usamodzielnioną i niezależną, nie ukończyła szkoły średniej, „lubiła alkohol, chociaż alkoholiczką nie była", „pochodziła z nienormalnej rodziny" i brakowało jej wzorców „prawdziwej katolickiej rodziny i małżeństwa”. Nic z tego wyliczenia, także przy łącznym rozpatrywaniu, nie prowadzi do wniosku o niezdolności do podjęcia istotnych obowiązków małżeńskich. Nie widać w materiale dowodowym żadnych faktów, które świadczyłoby o takiej niezdolności, w szczególności nie udowodniono uzależnienia alkoholowego (Trybunał też stwierdza, że nie była alkoholiczką, a jedynie „lubiła” alkohol). Swiadkowie podają, że strony były „zbyt młode, ale jest to stwierdzenie oparte na doświadczeniu życiowym, wcale nie równoznaczne ze 
stwierdzeniem pozostawania przez strony poniżej przeciętnej osiąganej przez osoby takiego wieku, o których przecież nie można generalnie powiedzieć, iż są niedojrzałe do małżeństwa. Warto przytoczyć zeznania matki pozwanej, która, gdy chciała powstrzymać ją przed zawarciem małżeństwa, usłyszała: „wiem co robię". Nie chodzi wprawdzie w sprawie o to, czy pozwana, wiedziała, co robi", ale stwierdzenie takie przeczy przypuszczeniu o jej braku niezależności. Przeciwnie, zachowanie pozwanej dowodzi dużej niezależności. Wystarcza przytoczyć zeznania ojca powoda o „podlapaniu fajnego chłopaka" (I, k.50).

3. W odniesieniu do powoda Trybunal II instancji stwierdza: „Powód był bardzo młodym człowiekiem - miał 18 lat. Pod każdym względem nie był przygotowany do małżeństwa. Nie byl samodzielny pod względów materialnym. Dopiero co podjął pracę zawodową. W podejmowaniu decyzji życiowych był uzależniony od swoich rodziców. Powód do tego małżenstwa był przymuszony szantażem pozwanej, która będąc $z$ nim w ciąży przedślubnej groziła popełnieniem samobójstwa, jeśli się $\mathrm{z}$ nią nie ożeni. Powód nie chciał małżeństwa $\mathrm{z}$ pozwaną, ale nie widzial innego wyjścia jak ślub. Nie kochał pozwanej, niechętnie do niej się odnosił (potwierdzają to rodzice powoda). Gdy dowiedział się o ciąży, miał zerwać znajomość z pozwaną. Jak zeznaje - modlił się nawet o śmierć dzieci, myślał o swojej poprzedniej dziewczynie. Wstydził się i bał. Chciał tylko spokoju, a nie małżeństwa. Nie mogąc uniknąć niechcianego ślubu w końcu poszedł do niego, ale nie zamierzał wiązać się z pozwaną na zawsze. Mówil, że i tak nie będzie z nią mieszkał. Odbyło się wesele, pomimo że ślub trzeba było odłożyć. Rodzina pozwanej zadbała o to, aby po weselu powód pozostał u nich. Choć dzieci zmarły na dwa tygodnie przed nowym terminem ślubu kościelnego, było za późno na wycofanie się, tym bardziej, że teraz już miały dużo do powiedzenia rodziny stron. Matka pozwanej bez wiedzy powoda załatwiła nowy termin ślubu kościelnego. W takiej sytuacji przygnieciony lawiną wydarzeń osiemnastoletni, nieśmiały chłopak, napiętnowany opinią młodocianego ojca, uznany powszechnie za męża, po przeżyciu szantaży przedślubną ciążą i groźbą samobójstwa, nie mógł być na tyle trzeźwy i odporny, aby nie pójść do ślubu kościelnego" (II, k.80-81). Trudno tu dostrzec przesłanki orzeczenia o niezdolności powoda do podjęcia istotnych obowiązków małżeńskich, które wszak wobec opinii biegłego musiałyby rysować się tym wyraźniej.

Biegły stwierdza natomiast, że „okoliczności ograniczały zdolność powoda do swobodnego podjęcia decyzji o zawarciu małżeństwa". $\mathrm{Na}$ te 
okoliczności zwraca się uwage również w wyroku Trybunału II instancji. Rzeczywiście okoliczności zawarcia małżeństwa stron były niezwykłe: niespodziewana ciąża, nacisk środowiska (powód zerwał znajomość, gdy dowiedział się o ciąży, dopiero pytany, ,co dalej będzie" zgodził się na ślub), odwołanie ślubu tuż przed wyjazdem do kościoła i „wesele” bez pozwanej, śmierć noworodków bliźniaków, wrzawa w miasteczku - to wszystko przerastało 18-letniego chłopaka i powodowało, że zawierając małżeństwo nie miał wystarczającego, umożliwiającego mu swobodę decyzji, rozeznania. Sąd dochodzi przeto do wniosku, że pozwany był niezdolny do zawarcia małżeństwa z przyczyn, o których w k. 1095 n.2. Rozpatrzenie ważności małżenstwa z tytułu wolności wewnętrznej sugeruje też dekret Sygnatury Apostolskiej polecający Trybunałowi I instancji wyznaczenie biegłego, który pomógłby powodowi rozważyć, czy nie należy prowadzić sprawy z k. 1095 n.2. Trybunał I instancji nadesłał odpowiedź, że powód nie stawia żadnych wniosków. Co powód najwidoczniej zrozumiał w sensie wniosków dowodowych. Trudno wymagać od powoda rozeznania co do różnicy między niezdolnością do podjęcia istotnych obowiązków malżeńskich i brakiem wewnetrznej wolności. Nie zwalnia to jednak Sądu od ustalenia właściwego,, wynikającego $\mathrm{z}$ materiału dowodowego tytułu nieważności. Sad zgadza się z Trybunałem II instancji co do przesłanki mniejszej orzeczenia, mianowicie braku wewnętrznej wolności u powoda w czasie zawierania małżeństwa. A taki stan faktyczny wymaga przyporządkowania mu w przesłance większej k.1095 n.2. Skoro Sąd osiąga moralną pewność, iż udowodniono nieważność małżenstwa $\mathrm{z}$ wynikłego $\mathrm{z}$ braku wewnętrznej wolności braku rozeznania. Sąd nie może uchylić wyroku Trybunału II instancji tylko dlatego, że ten, opierając się na tych samych dowodach, orzekł nieważność małżeństwa $\mathrm{z}$ tytułu niezdolności do podjęcia istotnych obowiązków małżeńskich. Ponieważ Sąd orzekając nieważność małżeństwa na podstawie k. 1095 n.2 opiera się na tych samych faktach prawnych jak wyrok Trybunału II instancji, to zachodzi - także-zgodność co do podstaw roszczenia, a tym samym zgodność wyroków. Tak więc Sąd orzekając nieważność małżeństwa $\mathrm{z}$ innego tytułu niż to uczynił Trybunał II instancji, zatwierdza w odniesieniu do tezy dotyczącej powoda wyrok Trybunału II instancji.

Wobec powyższego Sąd Metropolitalny rozpatrzywszy w III instancji sprawę o nieważność malżeństwa BM-MK.

1. orzeka, iżnie udowodniono nieważności małżeństwa z tytułu niezdolności pozwanej do podjęcia istotnych obowiązków małzeńskich i tym samym uchyla tego tytułu wyrok Trybunału II instancji; 
2. orzeka, iż udowodniono nieważność małżeństwa $\mathbf{z}$ tytułu braku wystarczającego rozeznania po stronie powoda, i uznając to orzeczenie za równoznaczne $z$ wyrokiem Trybunału Ii instancji zatwierdza tenże wyrok o niezdolności powoda do zawarcia malżeństwa. Tym samym Sąd stwierdza i orzeka nieważność małżeństwa.

La sentenza del Tribunale Metropolitano di Katowice (in terza istanza) c. Sobański del 2 sette,bre 1997 in causa di nullità del matrimonio dal titolo del "gravis defectus discretionis iudicii" e della ,incapacitas" (la conformità delle sentenze)

\section{Som mario}

Nella sentenza (pro nullitate) si tratta del matrimonio contratto nel 1972, e accusato di nullità nel 1989 dal titolo della ,incapacitas" nonchè della simulazione di ambedue parti. Dopo la sentenza negativa (da tutti i titoli), il tribunale di II istanza ha aggiunto un nuovo titolo: 1', incapacitas" dell'attore sentenziando quindi "non constare" dalla simulazione, „constare" però dalla ,incapacitas". Finalmente il tribunale di III istanza, fondandosi sullo stesso materiale probatorio (riguardo alla „incapacitas") ha sentenziato per la nullità del matrimonio, però non dal titolo di „incapacitas", ma „ob gravem defectus discretionis iudicii". Nello stesso tempo il tribunale ha giudicato la conformità delle sentenze (di II e III istanza). 